\title{
Modeling the connectivity between sea scallop populations in the Middle Atlantic Bight and over Georges Bank
}

\author{
Rucheng C. Tian ${ }^{1, *}$, Changsheng Chen ${ }^{1,2}$, Kevin D. E. Stokesbury ${ }^{1}$, Brian J. Rothschild ${ }^{1}$, \\ Geoffrey W. Cowles ${ }^{1}$, Qichun Xu${ }^{1}$, Song Hu${ }^{1}$, Bradley P. Harris ${ }^{1}$, Michael C. Marino $\mathrm{II}^{1}$
}

${ }^{1}$ Department of Fisheries Oceanography, School for Marine Science and Technology, University of Massachusetts Dartmouth, New Bedford, Massachusetts 02744, USA

${ }^{2}$ Marine Ecosystem and Environmental Laboratory, Shanghai Ocean University, 999 Hucheng Huan Road, 201306 Shanghai, China

\begin{abstract}
The dispersion and settlement of sea scallop larvae spawned on Georges Bank (GB) and in the Great Southern Channel (GSC) were explored using an individual-based population dynamics model. The model consisted of 4 pelagic life stages (egg, trochophore, veliger, and pediveliger) and 3 benthic life stages (juvenile, young adult, and adult). It was driven by the 1995 to 2005 hindcast flow field predicted by the Finite Volume Coastal Ocean Model (FVCOM) in the Gulf of Maine (GOM), with spawning stocks specified by field survey data. In 1998, 2001, 2004, and 2005, a large amount of larvae drifted southward along the shelf break to the Middle Atlantic Bight (MAB). The potential for long-distance southward transport of larvae was dependent on the upstream flow conditions on the Nova Scotian Shelf, climate forcing, and the timing and location of spawning on GB. The model also predicts considerable larval exchange between the GB and the GSC subpopulations, with $83 \%$ of larvae settled in the GSC being spawned on GB, and $46 \%$ of larvae settled on GB being spawned in the GSC on average from 1995 to 2005.
\end{abstract}

KEY WORDS: Sea scallop · Individual-based model · Lagrangian simulation · Georges Bank

\section{INTRODUCTION}

The sea scallop Placopecten magellanicus is among the most valuable bivalves, and is currently second (to American lobster) among eastern US and Canadian fisheries (Naidu \& Robert 2006). Sea scallops are found on the continental shelf of the western North Atlantic from Newfoundland to North Carolina. Georges Bank (GB) represents the single largest scallop bed (31 $000 \mathrm{~km}^{2}$; Brand 1991), with the Middle Atlantic Bight (MAB) becoming increasingly important in recent years (Naidu \& Robert 2006). As with many marine living resources, the scallop fishery stocks are subject to environmental changes and exploitation pressure, leading to fluctuations in fishery landings. The US scallop landings from GB peaked at $9982 \mathrm{mt}$ (adductor meat weight) in 1990 and declined to $1205 \mathrm{mt}$ in 1994 (NEFSC 2007). Three closed areas
(17000 $\mathrm{km}^{2}$ in total) have been implemented since December 1994 on GB, in the Great Southern Channel (GSC), and on the southern New England Shelf (NES) to protect declining ground fish stocks (Murawski et al. 2000). Following the closures, the scallop populations in these areas increased dramatically, by a factor of 4 by 1996, by a factor of 9 by 1998, and by a factor of 18 by 2000 (Murawski et al. 2000, Hart \& Rago 2006). However, the increase in scallop populations did not significantly improve the recruitment on GB (recruitment is defined as the number of scallops that grow to $2 \mathrm{yr}$ old per year). The log-transformed mean recruitment indices (mean $\log _{\mathrm{e}}$ per tow) was 3.96 prior to the closure from 1980 to 1994 and 4.22 after the closure from 1996 to 2003 (Hart \& Rago 2006). The weak spawner-recruit relationship was explained by density-dependent inhibition and saturation (Stokesbury et al. 2004, Hart \& Rago 2006). In contrast to GB, strong 
recruitment and increases in scallop population have been observed in the MAB since 1998 (Hart \& Rago 2006). Subsequently, scallop landings from the MAB increased considerably, from $2891 \mathrm{mt}$ in 1998 to $24497 \mathrm{mt}$ in 2004 (NEFSC 2007). Here we examined a potential connection between the aforementioned increase in scallop recruitment in the MAB and the increase in the spawning stocks on GB.

Although sea scallops are a sedentary species with limited ability to migrate (Posgay 1981, Melvin et al. 1985), their pelagic larvae are subject to current drifting, which can result in effective connection between geographically-separated populations. Larval retention and dispersal are of particular concern on GB due to the complex circulation (Fig. 1). Three major currents dominate: the Western Maine Coastal Current (WMCC) with 1 branch crossing over the northern end of GSC onto GB, the tidal-mixing-front recirculation resulting from tidal rectification over steep bottom topography, and the along-shelf current on the southern flank of GB, which flows southwestward towards the MAB. The tidal-mixing-front recirculation is believed to play a key role in larval retention and population maintenance on GB (Tremblay et al. 1994). The along-shelf current, however, can transport larvae away from the region (Polacheck et al. 1992, Lozier \&

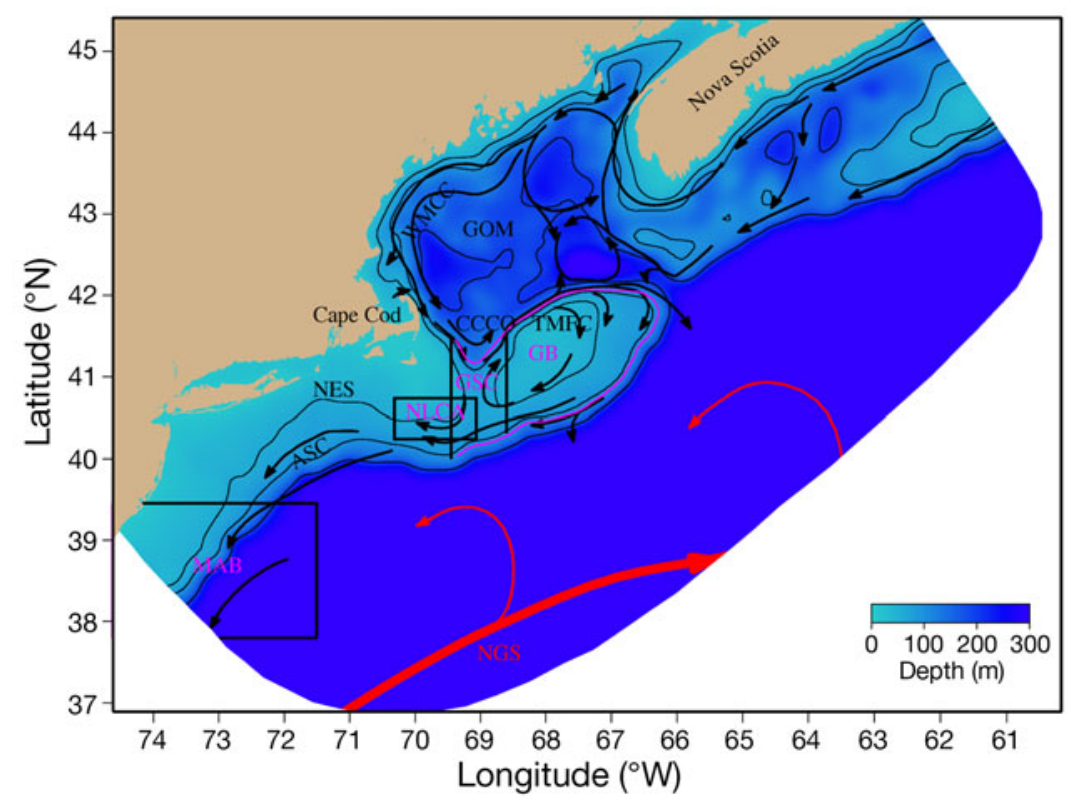

Fig. 1. Model domain and summertime general subtidal circulation pattern (reproduced from Beardsley et al. 1997, Fratantoni \& Pickart 2003, Townsend et al. 2006). Black continuous lines: 60,100, and $200 \mathrm{~m}$ isobaths. Water depth was truncated to $300 \mathrm{~m}$ off the shelf break (ASC: Along-Shelf Current; CCCO: Coastal Current Cross-Over; GOM: Gulf of Maine; GB: Georges Bank; GSC: Great Southern Channel; MAB: Middle Atlantic Bight south to the Hudson Canyon and bordered by the open boundary of the model domain on the southwestern side; WMCC: West Main Coastal Current; NGS: Northern edge of the Gulf Stream; NLCA: Nantucket Lightship Closed Area; TMFC: Tidal Mixing Front Recirculation)
Gawarkiewicz 2001). These currents are subject to local forcing such as wind (Noble et al. 1985, Houghton et al. 1988) as well as remote forcing such as the coldwater intrusions from the Nova Scotian Shelf (Greene \& Pershing 2003) and warm core rings from the Gulf Stream (Beardsley et al. 1985). Variations in the circulation can lead to interannual changes in larval dispersion and retention. It is generally understood that scallop spat that settle in the MAB derive from the southern NES and those that settle on the southern NES were likely spawned on GB (NEFSC 2004). However, the hypothesis of a connection between the scallop populations in the MAB and over GB has not been sted. By employing an individual-based population dynamics model for sea scallops driven by the state-ofthe-art Finite-Volume Coastal Ocean Model (FVCOM) with spawning stocks specified by field observation, we conducted a model analysis on the dispersion and the GSC.

Using FVCOM, a hindcast model run was performed to establish the physical fields of velocity, turbulence, temperature, and salinity over the period 1995 to 2005 (Cowles et al. 2008). The model adequately predicted the temporal and spatial variations of subtidal currents and water stratification on the NES (Cowles et al. 2008). Estimates of scallop abundance and distribution were derived from the comprehensive, high-resolution scallop video survey conducted in the GB-GSCNES region (Stokesbury et al. 2004). The aforementioned circulation fields and scallop distribution data are the basic elements of our numerical experiment.

\section{MATERIALS AND METHODS}

Model description. The sea scallop has a well defined life cycle with explicit ontogenetic life stages (Stewart \& Arnold 1994). Based on the scallop life cycle, we developed a Lagrangian individualbased population dynamics model, which consists of 4 pelagic stages (egg, trochophore, veliger, and pediveliger) and 3 benthic stages (juvenile, young adult, and adult; Fig. 2). In the model, the individual development is based on age, with eggs $<2 \mathrm{~d}$ old, trochophores 2 to $5 \mathrm{~d}$, veligers 5 to $35 \mathrm{~d}$, pediveligers $>35 \mathrm{~d}$, juveniles $<2 \mathrm{yr}$, young adults 2 to $4 \mathrm{yr}$, and adults $>4$ yr (Stewart \& Arnold 1994, Tremblay et al. 1994). The pelagic life stages are essentially differentiated by 


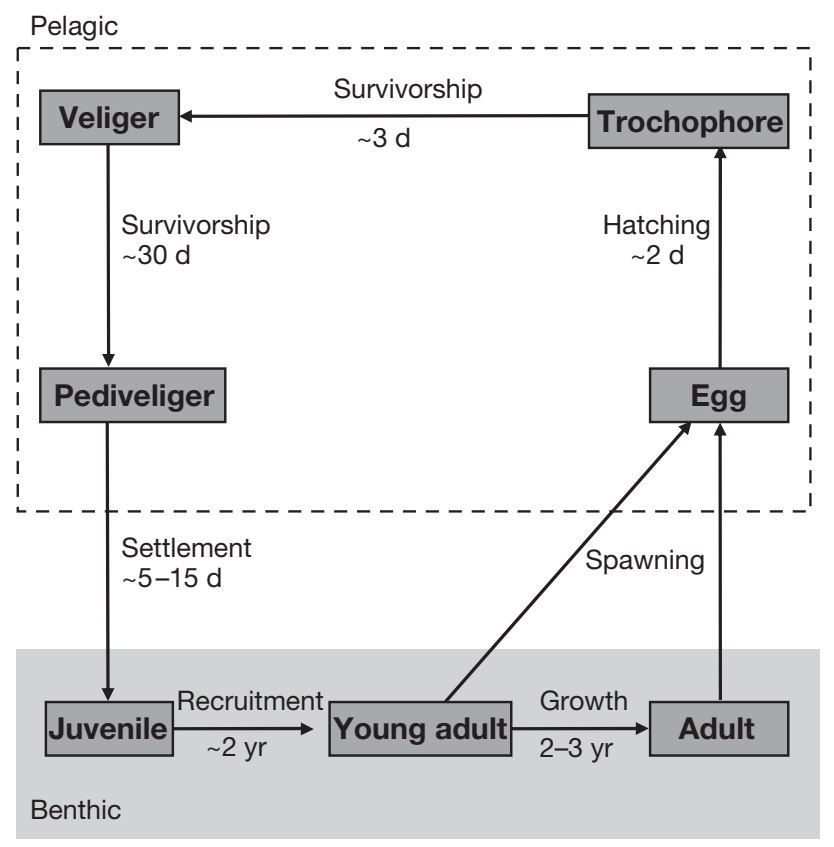

Fig. 2. Placopecten magellanicus. Population dynamics model including 4 pelagic stages (egg, trochophore, veliger, and pediveliger) and 3 benthic stages (juvenile, young adult, and adult). Life-stage durations are based on Stewart \& Arnold (1994) and Tremblay et al. (1994)

their behavioral vertical migration and the benthic stages by their reproductive capability. As the spawning stocks were specified by field survey data (see the following section), the benthic stages were not specifically simulated in this application. All pelagic life stages are subject to current drifting, random-walk dispersal, and behavioral vertical migration. Due to the large number of eggs and larvae, we used the Lagrangian ensemble particle method, with each particle representing an ensemble of larvae. The Lagrangian trajectory equation for ensemble particles is:

$$
\Delta P_{i}(\vec{x}, t)=\vec{u}_{x} \Delta t+R\left(A_{x}\right)+R\left(K_{z}\right)+W_{m}\left(P_{i}, t\right) \Delta t
$$

where $\Delta P_{i}(\vec{x}, t)$ is the positional change of the ensemble particle $i$ at time $t_{i} \vec{u}_{X}$ is the 3 -dimensional (3D) current vector, $R\left(A_{x}\right)$ and $R\left(K_{z}\right)$ represent horizontal and vertical random walks determined by the local horizontal $\left(A_{x}\right)$ and vertical $\left(K_{z}\right)$, model-computed eddy diffusivity coefficients. $W_{m}\left(P_{i}, t\right)$ is the behavioral vertical migration speed, and $\Delta t$ is the time step of the model integration. The vertical random walk is computed as:

$$
R\left(K_{z}\right)=K^{\prime}{ }_{z} \Delta t+r\left\{2 \sigma^{-1}\left[K_{z}+K_{z}^{\prime}(\Delta t) \Delta t\right]\right\}^{1 / 2}
$$

where $r$ is a random process with a uniform distribution between -1 and 1 , and $\sigma$ is the standard deviation of $r$ (=1/3; Visser 1997).

The parameterization of the vertical migration speed is:

$$
W_{m}\left(P_{1}, \text { age }\right)=\left\{\begin{array}{l}
0 \mathrm{~mm} \mathrm{~s}^{-1} ; \text { when age }<2 \mathrm{~d} \\
0.3 \mathrm{~mm} \mathrm{~s}^{-1} ; \text { when } 2 \leq \text { age }>5 \mathrm{~d} \\
0.1 \mathrm{~mm} \mathrm{~s}^{-1} ; \text { when } 5 \leq \text { age }<35 \mathrm{~d} \\
-1.7 \mathrm{~mm} \mathrm{~s}^{-1} ; \text { when age } \geq 35 \mathrm{~d}
\end{array}\right.
$$

Eggs are spawned near the bottom and are subject to passive drifting. After $2 \mathrm{~d}$, eggs hatch into trochophores, which migrate upward to the surface layers with a migration speed of $0.3 \mathrm{~mm} \mathrm{~s}^{-1}$ (ranging from 0.1 to $0.7 \mathrm{~mm} \mathrm{~s}^{-1}$, Tremblay et al. 1994). On Day 5, trochophores develop into veligers, which are essentially subject to current drifting in the surface mixed layer. At an age of $35 \mathrm{~d}$, veligers develop into pediveligers, which actively descend to the bottom at a speed of $-1.7 \mathrm{~mm} \mathrm{~s}^{-1}$ and search for suitable substrate for settlement (Tremblay et al. 1994).

The number of larvae in each ensemble particle is determined in 2 phases: the spawning period before the release and larval development after the release. During the spawning period before the release, the number of eggs in each ensemble particle is determined by the spawning activity, which was assumed to have a normal distribution in time. Following the release, the number of larvae in each ensemble particle is subject to an instantaneous mortality at each time step. The enumeration of larvae in each ensemble particle is:

$$
P_{i}(n, t)=\left\{\begin{array}{c}
N_{\text {scallop }} S_{\text {egg }} \int_{t_{0}}^{t} \frac{1}{\sqrt{2 \pi} \sigma} \mathrm{e}^{-\frac{1}{2}\left(\frac{t-t_{\mathrm{m}}}{\sigma}\right)^{2}} \mathrm{~d} t_{;} \\
\text {(Spawning before release) } \\
P_{i}\left(n, t_{-1}\right) \mathrm{e}^{-M \mathrm{~d} t} ; \\
\text { (Mortality after release) }
\end{array}\right.
$$

where $P_{i}(n, t)$ is the number of eggs (or larvae) at time $t$ in the ensemble particle $P_{i}, N_{\text {scallop }}$ is the total scallops in a simulation cell, $S_{\text {egg }}$ is the total eggs spawned by each individual adult scallop in 1 season, $M$ is the instantaneous mortality (a constant mortality of $0.25 \mathrm{~d}^{-1}$ was used based on McGarvey et al. 1992), $t_{0}$ is the time when the ensemble particle $P_{i}$ is formed, $t_{-1}$ the previous time step, $t_{\mathrm{m}}$ the time of maximum spawning, and $\mathrm{d} t$ is the time step of model integration. The normal distribution was integrated using the error function erf:

$$
F(t)=\int_{-\infty}^{x} \frac{1}{\sqrt{2 \pi}} \mathrm{e}^{-\frac{1}{2} x^{2}}=\frac{1}{2}\left[1+\operatorname{erf}\left(\frac{x}{2}\right)\right]
$$

where $x=\left(t-t_{\mathrm{m}}\right) / \sigma$.

Application to GB. In 2003, a comprehensive video survey of sea scallop abundance was conducted in the GB region (Stokesbury et al. 2004). Results from this data set were used to specify the spawning stock. This survey did not include the Canadian portion of GB. To have a complete estimation of the spawning stocks on the Canadian side, we used the scallop abundance 
data reported by Thouzeau et al. (1991). This dataset only includes scallops age 3 and older in abundance estimates, whereas the 2003 survey data of Stokesbury et al. (2004) included the entire scallop population, basically from $1 \mathrm{yr}$ and older. Young scallops from age 2 may begin to reproduce, but their fecundity and the reliability of eggs are much lower than those of adults. In order to have a consistent age range for both the US and Canadian portions of GB, we determined the abundance of scallops older than age 3 from the survey data using the von Bertalanffy growth function (Thouzeau et al. 1991). Although the 2 data sets were $15 \mathrm{yr}$ apart, we used the same spawning stock for all simulated years so that the interannual variability in modelcomputed larval settlement was driven only by physical forcing. An average of 50 million eggs per adult scallop during 1 spawning season (Langton et al. 1987) was used in the model.

On GB, fall spawning generally occurs in late September or early October (Shumway et al. 1988, McGarvey et al. 1992, DiBacco et al. 1995). The duration of spawning varies according to environmental conditions such as temperature and food supply, ranging from less than $1 \mathrm{wk}$ to more than 1 mo (Posgay \& Norman 1958, Posgay 1976, Mullen \& Moring 1986, DiBacco et al. 1995). We assumed that the maximum spawning occurred on 20 September with a standard deviation of $1 \mathrm{wk}$. The model was integrated over a 3 mo period from 1 September to 30 November of each year using a time step of $2 \mathrm{~min}$. Scallop spawning was simulated at each time step, but spawned eggs were first accumulated in an ensemble particle in each simulation cell. When the total number of eggs reached a pre-defined number ( $>10^{13}$ individuals), an ensemble particle was released and a new ensemble particle was initiated in the same simulation cell. Multiple ensemble particles can be thus formed in a single simulation cell according to the spawning stock density. At the end of the spawning season ( $3 \mathrm{wk}$ after the maximum spawning day), all ensemble particles containing more than a single egg were released. With the abovedescribed parameterization, 4412 ensemble particles containing a total of $1.99 \times 10^{17}$ eggs were released during the simulation (Fig. 3). The first ensemble particle was released on Day 6 of the simulation (6 September), and the last was released on Day 41 (11 October). The number of eggs in each ensemble particle varied from $1.2 \times 10^{11}$ to $5.6 \times 10^{13}$ with an average of $4.5 \times 10^{13}$.

Scallop larvae are known to aggregate above the pycnocline in stratified regions on GB (Tremblay \& Sinclair 1990). Based on long-term climatological data on GB and in the GSC, Tremblay et al. (1994) used the global average of the thermocline depth $(23 \mathrm{~m})$ to specify the depth of larval drift in the region. Following

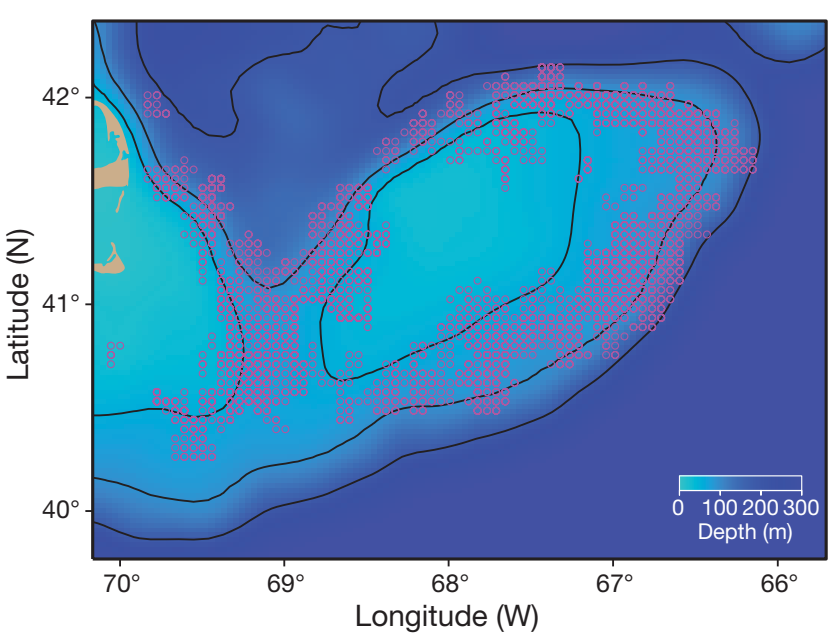

Fig. 3. Placopecten magellanicus. Initial positions of scallop larvae ensemble particles. In total, 4412 ensemble particles containing $1.99 \times 10^{17}$ eggs were released. Some of the ensemble particles were superimposed on model grids depending on the density of the spawning population. Continuous lines: 60,100 , and $200 \mathrm{~m}$ isobaths

their efforts, we assumed that when veligers attained a depth of $23 \mathrm{~m}$, their vertical migration was arrested and for the remainder of the simulation they were subject only to passive drifting and a horizontal random walk. Since this setup includes the available field observations such as larval drifting depth and settlement duration (see the following paragraph), we refer to it as the 'Standard run' (Table 1). Given the possible variability in the depth of the thermocline, we performed 3 sensitivity-analysis runs, which included (1) maintaining a vertical random walk during the entire simulation so that the larvae were distributed in the surface mixed layer and thus drifted at different depths ('Random-walk' run in Table 1), (2) maintaining both a vertical random walk and vertical migration so that larvae can actively migrate up to the surface, but are redistributed in the surface mixed layer through dispersal ('Surface-drift' run in Table 1), and (3) deactivating both vertical migration and vertical random walk at the depth of $50 \mathrm{~m}$ ('50-m-drift' run in Table 1).

At settlement, spat prefer coarse substrates such as pebble, gravel, and shell fragments to fine substrates like clay and fine sand (Culliney 1974, Thouzeau et al. 1991). In the model, the settlement of larvae was determined by the suitability of the substrate. We digitized the sediment distribution on GB reported by Twichell et al. (1987) and used this to derive a probability of settlement (Fig. 4). Gravels were assumed to have a settlement probability of 0.2 (i.e. larvae had a $20 \%$ probability of settlement upon reaching gravel substrates, with unsettled larvae being reflected back ca. $1 \mathrm{~m}$ above the bottom and continuing to search for suitable 
Table 1. Experimental design. All experiments included passive drifting and pediveliger downward migration. Upward migration and random walk were included in all experiments until the larvae attained the pre-defined depth of drift and subsequently were maintained or deactivated according to the design of each experiment. In the Standard run, the settlement probability $\left(P_{\mathrm{S}}\right)$ was assigned the value of 0.2 for gravel, 0.05 for sand, and 0.01 for fine sand. The settlement probability was reduced by half in the fifth sensitivity-analysis experiment (Reduced-settlement-probability run) and enhanced by a factor of 2 in the sixth experiment (Increased-settlement-probability run)

\begin{tabular}{|lcccc|}
\hline Experiment & Drifting depth $(\mathrm{m})$ & Random walk & Migration & Settlement probability \\
\hline (1) Standard run & 23 & Off & Off & $P_{\mathrm{S}}$ \\
(2) Random-walk & 23 & On & Off & $P_{\mathrm{S}}$ \\
(3) Surface-drift & Surface & On & On & $P_{\mathrm{S}}$ \\
(4) 50 -m-drift & 50 & Off & Off & $P_{\mathrm{S}}$ \\
(5) Reduced-settlement-probability & 23 & Off & Off & $0.5 P_{\mathrm{S}}$ \\
(6) Increased-settlement-probability & 23 & Off & Off & $2 P_{\mathrm{S}}$ \\
\hline
\end{tabular}

substrate), coarse sand 0.05 , and fine sand 0.01 . These values were determined so that the duration of larval settlement lasted about 1 mo (Culliney 1974). To assess the potential influence of the settlement probability on simulation results, we added 2 additional sensitivityanalysis runs by (1) reducing the settlement probability by 2 ('Reduced-settlement-probability' run in Table 1) and (2) doubling the settlement probability ('Increased-settlement-probability' run in Table 1) relative to the Standard Run.

Physical simulation. The setup of the circulation model was described in detail by Cowles et al. (2008). Briefly, the model domain covers the Gulf of Maine (GOM)/GB region and is enclosed by an open boundary extending from the Nova Scotian Shelf south to New Jersey (Fig. 1). Increased grid resolution is used over slope regions and tidal mixing fronts, with a horizontal resolution $\sim 1.0$ to $2.0 \mathrm{~km}$ around the shelf-break of $\mathrm{GB}, 2$ to $3 \mathrm{~km}$ over the top of $\mathrm{GB}$, and $10 \mathrm{~km}$ in the interior of the GOM and in the deep regions near the

(A) Sediment distribution

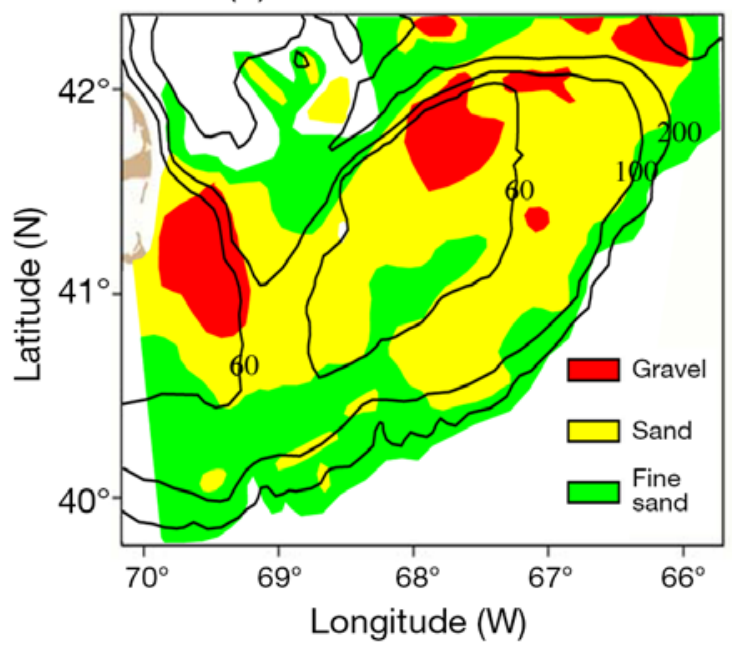

open boundary. In the vertical, $31 \sigma$-levels are employed, providing a resolution of $\sim 1.3$ to $4 \mathrm{~m}$ on GB where the water depth is less than $120 \mathrm{~m}$, and $10 \mathrm{~m}$ in the open ocean region off the shelf break where the bathymetry is truncated to $300 \mathrm{~m}$.

The model was driven by surface forcing of wind and heat fluxes computed by the meteorological model MM5, open boundary surface elevation specified using 5 tidal constituents (M2, S2, N2, O1, and K1) and freshwater discharge from the primary rivers discharging into GOM. The inflow from the Nova Scotian Shelf was computed using a sea surface slope determined from observed density distribution and Ekman transport from local wind forcing. Nudging to the monthly data at the inflow boundary was also employed to constrain the inflow transport and hydrography. Data assimilation of sea surface temperature (SST) was conducted on a daily basis. For integration of the model equations, FVCOM uses a 'mode-splitting' approach. A time step of $12 \mathrm{~s}$ was used for the external mode (2D barotropic

\section{(B) Settlement probability}

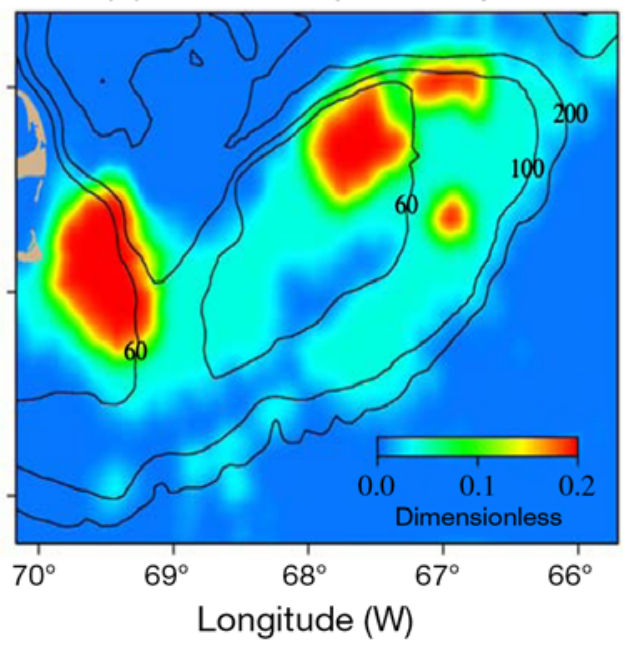

Fig. 4. (A) Sediment distribution (reproduced from Twichell et al. 1987) and (B) settlement probability $\left(P_{\mathrm{S}}\right)$ determined based on sediment types $\left(P_{\mathrm{S}}=0.2\right.$ for gravel, 0.05 for sand, and 0.01 for fine sand) 
terms) and $120 \mathrm{~s}$ for the internal mode (3D baroclinic terms). The model was integrated continuously from 1995 to 2005, and the predicted currents and water temperatures were verified by comparisons to observed currents and CTD profiles that were not included in the data assimilation (Cowles et al. 2008).

\section{RESULTS}

\section{Long-distance transport and interannual variability}

We first present the results predicted by the Standard run. The sensitivity-analysis runs were conducted to analyze the influence of our assumptions, and the results from those runs are presented in the 'Sensitivity analysis' section.

Only the spawning stocks on GB and in the GSC were included in the simulation. However, the spawned larvae drifted hundreds of kilometers away from their spawning grounds, extending as far south as the MAB in certain years (Fig. 5). In 2005, for example,
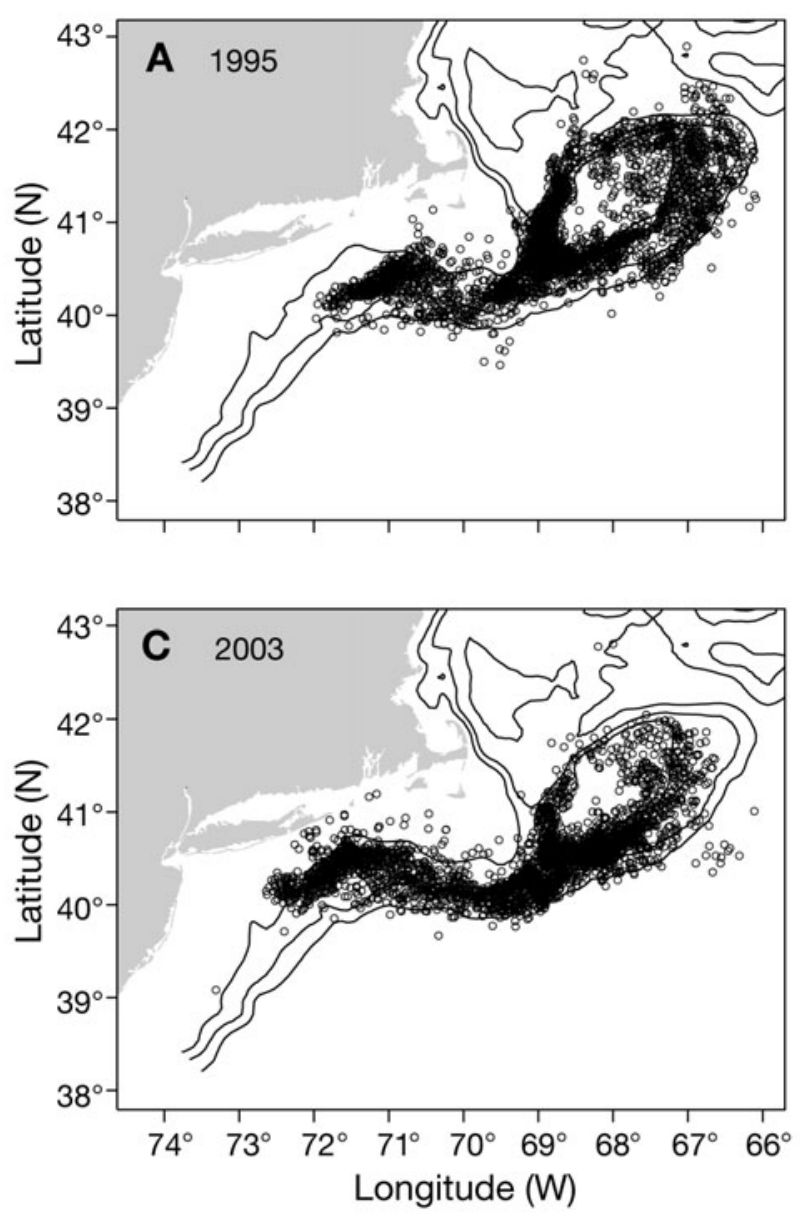

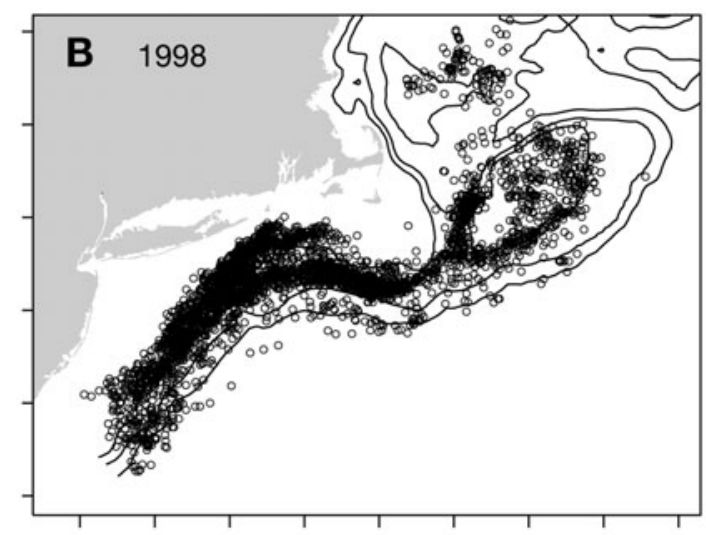

the larval settlement in the MAB was more numerous than the total larvae settlement on GB and in the GSC (Fig. 6). The long-distance transport of larvae to the MAB fluctuated widely on an interannual basis, with all larvae restricted to the southern NES in 4 of the 11 simulated years.

The total number of larvae settled on GB within the 18 to $110 \mathrm{~m}$ isobath range, which was defined as the scallop essential habitat (Hart \& Chute 2004), averaged $4.82 \times$ $10^{12}$ over the $11 \mathrm{yr}$ with a coefficient of variation (CV) of $35 \%$ (Table 2). The maximum number of larvae settled on GB $\left(7.62 \times 10^{12}\right)$ simulated in 2003 was 3.5 times higher than the minimum $\left(2.19 \times 10^{12}\right)$ simulated in 2005 (Table 2). Larvae settled in abundance along the tidal mixing front around the $60 \mathrm{~m}$ isobath (Fig. 7), which coincided with the track of the tidal-mixing-front recirculation. The donut-like distribution of larval settlement showed similarity to the adult scallop distribution (Stokesbury et al. 2004), but in 1996 and 2004, a notable number of larvae drifted onto the crest of GB where few adult scallops were observed, indicating that cross-front dispersion of scallop larvae occurred in some years.

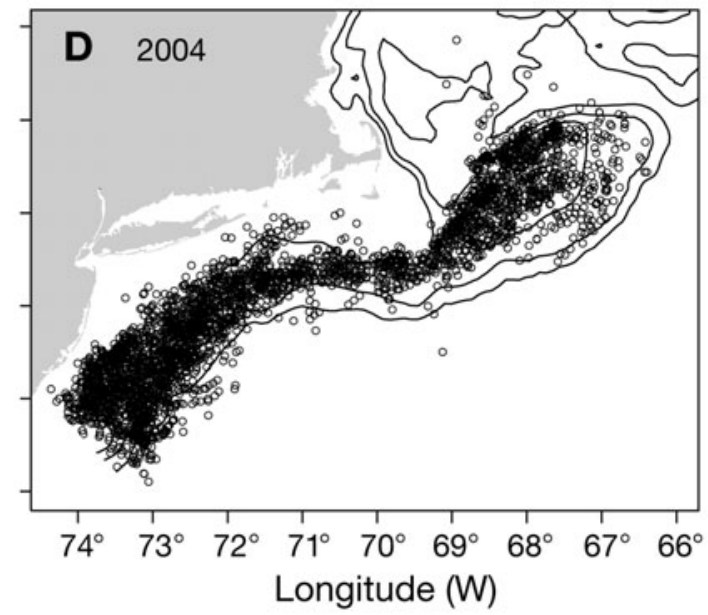

Fig. 5. Placopecten magellanicus. Final settlement of scallop larvae ensemble particles at the end of the simulation predicted

by the Standard run. Continuous lines: 60, 100, and $200 \mathrm{~m}$ isobaths 


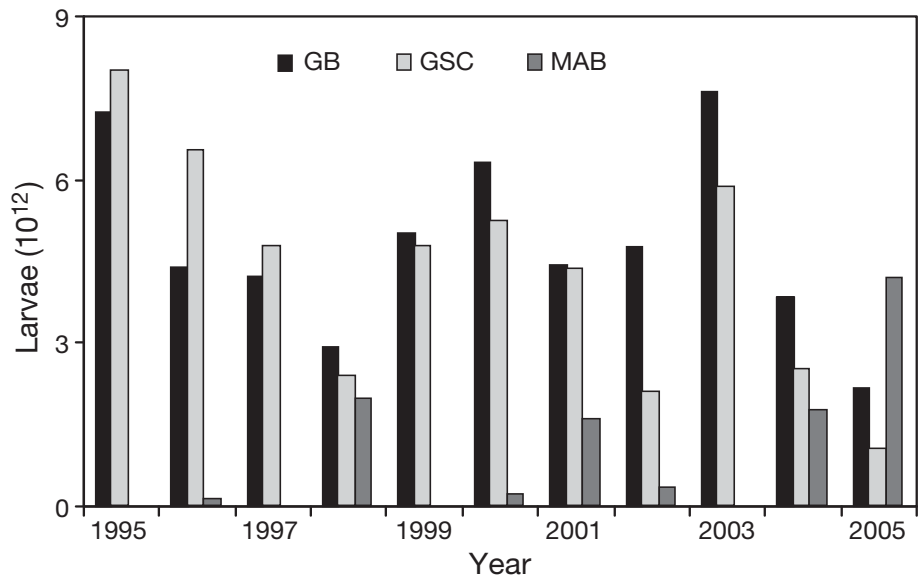

Fig. 6. Placopecten magellanicus. Total larvae settled on Georges Bank (GB), in the Great Southern Channel (GSC), and to the Middle Atlantic Bight within the 18 to $110 \mathrm{~m}$ isobaths of scallop essential habitat predicted by the Standard run (sub-domains defined in Fig. 1)
The total number of larvae settled in the GSC varied from $1.06 \times 10^{12}$ in 2005 to $7.98 \times 10^{12}$ in 1995 with a global average of $4.33 \times 10^{12}$ and a CV of $49 \%$ (Fig. 6, Table 2). The GSC had a higher abundance of settled larvae than GB (Fig. 7). The average larval abundance in the GSC ranged from 120 larvae $\mathrm{m}^{-2}$ in 2005 to 980 larvae $\mathrm{m}^{-2}$ in 1995, with a global mean of 508 larvae $\mathrm{m}^{-2}$ over the $11 \mathrm{yr}$, whereas the settlement on GB ranged from 75 larvae $\mathrm{m}^{-2}$ in 2005 to 250 larvae $\mathrm{m}^{-2}$ in 2003 with a global mean of 163 larvae $\mathrm{m}^{-2}$. However, GSC settlement was also subject to larger fluctuations than GB, with an interannual variability up to 7.5-fold (maximum versus minimum). With GB and the GSC combined, the interannual variability in larval settlement was a factor of 5. Larvae also settled in abundance in the Nantucket Lightship Closed Area (NLCA) located on the southern NES,

Table 2. Placopecten magellanicus. Total number of larvae (in $10^{12}$ individuals) settled on Georges Bank (GB), in the Great Southern Channel (GSC), to the Middle Atlantic Bight (MAB), and in the Gulf of Maine (GOM) predicted by the 6 simulation experiments defined in Table 1. SR: Standard run; RW: Random-walk run; SD; Surface-drift run; 50 m: 50-m drift run; RSP: Reduced-settlement-probability run; ISP: Increased-settlement-probability run; STD: standard deviation; TP: Two-tailed $t$-test probability to wrongly reject the null hypothesis that a sensitivity run is undifferentiated from the Standard run; -: no value

\begin{tabular}{|c|c|c|c|c|c|c|c|c|c|c|c|c|c|c|c|}
\hline Region & Run & 95 & 96 & 97 & 98 & 99 & 00 & 01 & 02 & 03 & 04 & 05 & Mean & $\mathrm{CV}$ & $\mathrm{TP}$ \\
\hline \multirow[t]{9}{*}{ GB } & SR & 7.25 & 4.41 & 4.23 & 2.94 & 5.03 & 6.34 & 4.44 & 4.77 & 7.62 & 3.85 & 2.19 & 4.82 & 0.35 & - \\
\hline & RW & 9.43 & 5.28 & 4.44 & 3.84 & 4.37 & 5.77 & 5.43 & 4.44 & 7.08 & 3.97 & 3.50 & 5.23 & 0.33 & 0.17 \\
\hline & $\mathrm{SD}$ & 9.46 & 4.72 & 3.40 & 3.49 & 3.89 & 6.80 & 6.40 & 6.37 & 6.86 & 3.50 & 3.13 & 5.37 & 0.39 & 0.22 \\
\hline & $50 \mathrm{~m}$ & 11.4 & 8.98 & 7.94 & 5.41 & 7.78 & 9.37 & 7.28 & 6.37 & 12.7 & 7.44 & 5.76 & 8.22 & 0.28 & $5 \times 10^{-7}$ \\
\hline & RSP & 6.30 & 3.87 & 3.76 & 3.35 & 4.16 & 5.60 & 3.76 & 4.14 & 6.37 & 3.31 & 1.91 & 4.23 & 0.32 & $1 \times 10^{-3}$ \\
\hline & ISP & 7.91 & 4.80 & 4.59 & 3.21 & 5.44 & 6.98 & 4.90 & 5.24 & 8.45 & 4.15 & 2.43 & 5.28 & 0.35 & $1 \times 10^{-5}$ \\
\hline & Mean & 8.63 & 5.34 & 4.73 & 3.71 & 5.11 & 6.81 & 5.37 & 5.22 & 8.18 & 4.37 & 3.15 & 5.53 & 0.34 & - \\
\hline & STD & 1.84 & 1.84 & 1.64 & 0.88 & 1.42 & 1.37 & 1.30 & 0.96 & 2.33 & 1.54 & 1.41 & 1.39 & 0.04 & - \\
\hline & $\mathrm{CV}$ & 0.21 & 0.34 & 0.35 & 0.24 & 0.28 & 0.20 & 0.24 & 0.18 & 0.28 & 0.35 & 0.45 & 0.17 & 0.11 & - \\
\hline \multirow[t]{9}{*}{ GSC } & SR & 7.98 & 6.55 & 4.79 & 2.37 & 4.78 & 5.24 & 4.37 & 2.09 & 5.86 & 2.52 & 1.06 & 4.33 & 0.49 & - \\
\hline & RW & 3.36 & 3.23 & 3.64 & 1.61 & 3.27 & 3.12 & 2.26 & 2.15 & 2.73 & 1.96 & 1.55 & 2.62 & 0.28 & $4 \times 10^{-3}$ \\
\hline & SD & 1.69 & 3.03 & 1.90 & 0.76 & 1.81 & 1.56 & 2.08 & 2.76 & 3.28 & 1.58 & 1.36 & 1.98 & 0.38 & $3 \times 10^{-3}$ \\
\hline & $50 \mathrm{~m}$ & 6.62 & 4.48 & 6.97 & 2.92 & 6.49 & 3.51 & 1.85 & 2.76 & 3.73 & 1.93 & 2.10 & 3.85 & 0.50 & 0.46 \\
\hline & RSP & 7.04 & 5.79 & 4.20 & 2.72 & 4.45 & 4.60 & 3.85 & 1.89 & 5.14 & 2.16 & 0.90 & 3.89 & 0.47 & $2 \times 10^{-3}$ \\
\hline & ISP & 8.62 & 6.99 & 5.13 & 2.57 & 5.17 & 5.54 & 4.65 & 2.38 & 6.26 & 2.69 & 1.15 & 4.65 & 0.48 & $3 \times 10^{-5}$ \\
\hline & Mean & 7.54 & 5.97 & 5.26 & 2.79 & 5.19 & 5.25 & 4.40 & 4.03 & 5.87 & 2.82 & 2.06 & 4.64 & 0.43 & - \\
\hline & STD & 2.70 & 1.95 & 1.37 & 0.98 & 1.36 & 2.28 & 2.70 & 4.36 & 3.06 & 1.42 & 1.79 & 2.00 & 0.10 & - \\
\hline & $\mathrm{CV}$ & 0.36 & 0.33 & 0.26 & 0.35 & 0.26 & 0.43 & 0.61 & 1.08 & 0.52 & 0.50 & 0.87 & 0.44 & 0.22 & - \\
\hline \multirow[t]{9}{*}{ MAB } & SR & 0.00 & 0.12 & 0.01 & 1.97 & 0.01 & 0.21 & 1.61 & 0.34 & 0.01 & 1.74 & 4.17 & 0.93 & 1.43 & - \\
\hline & RW & 0.01 & 0.60 & 0.14 & 3.70 & 0.77 & 1.30 & 3.94 & 0.45 & 0.02 & 4.13 & 3.92 & 1.73 & 1.03 & 0.02 \\
\hline & SD & 0.00 & 2.10 & 0.34 & 4.60 & 0.83 & 3.76 & 2.81 & 0.09 & 0.05 & 4.98 & 3.64 & 2.11 & 0.92 & 0.02 \\
\hline & $50 \mathrm{~m}$ & 0.00 & 0.01 & 0.00 & 0.29 & 0.00 & 0.04 & 2.31 & 0.09 & 0.00 & 0.52 & 1.09 & 0.40 & 1.82 & 0.13 \\
\hline & RSP & 0.00 & 0.10 & 0.01 & 2.34 & 0.01 & 0.20 & 1.30 & 0.29 & 0.00 & 1.59 & 3.55 & 0.85 & 1.41 & 0.34 \\
\hline & ISP & 0.00 & 0.12 & 0.01 & 2.12 & 0.00 & 0.20 & 1.79 & 0.35 & 0.01 & 1.88 & 4.54 & 1.00 & 1.44 & 0.07 \\
\hline & Mean & 0.00 & 0.51 & 0.09 & 2.50 & 0.27 & 0.95 & 2.29 & 0.27 & 0.02 & 2.47 & 3.49 & 1.17 & 1.34 & - \\
\hline & STD & 0.00 & 0.81 & 0.14 & 1.50 & 0.41 & 1.45 & 0.97 & 0.15 & 0.02 & 1.70 & 1.23 & 0.63 & 0.32 & - \\
\hline & $\mathrm{CV}$ & 2.45 & 1.59 & 1.60 & 0.60 & 1.52 & 1.52 & 0.42 & 0.55 & 1.25 & 0.69 & 0.35 & 0.54 & 0.24 & - \\
\hline \multirow[t]{9}{*}{ GOM } & SR & 1.34 & 0.26 & 3.20 & 1.03 & 1.63 & 0.51 & 0.42 & 2.63 & 1.22 & 0.32 & 0.90 & 1.22 & 0.78 & - \\
\hline & RW & 1.27 & 0.56 & 1.73 & 2.61 & 1.10 & 0.35 & 0.94 & 2.00 & 1.64 & 0.53 & 0.93 & 1.24 & 0.56 & 0.94 \\
\hline & $\mathrm{SD}$ & 9.46 & 4.72 & 3.40 & 3.49 & 3.89 & 6.80 & 6.40 & 6.37 & 6.86 & 3.50 & 3.13 & 5.27 & 0.39 & $2 \times 10^{-4}$ \\
\hline & $50 \mathrm{~m}$ & 0.83 & 0.13 & 1.51 & 0.84 & 1.12 & 0.30 & 0.17 & 0.87 & 1.31 & 0.33 & 0.38 & 0.71 & 0.67 & 0.02 \\
\hline & RSP & 1.00 & 0.22 & 2.17 & 1.64 & 1.07 & 0.33 & 0.28 & 1.71 & 1.02 & 0.30 & 0.80 & 0.96 & 0.69 & 0.08 \\
\hline & ISP & 1.65 & 0.31 & 4.22 & 1.20 & 2.20 & 0.64 & 0.48 & 3.43 & 1.51 & 0.43 & 0.92 & 1.54 & 0.83 & 0.01 \\
\hline & Mean & 2.59 & 1.03 & 2.71 & 1.80 & 1.84 & 1.49 & 1.45 & 2.84 & 2.26 & 0.90 & 1.18 & 1.82 & 0.65 & - \\
\hline & STD & 3.38 & 1.81 & 1.07 & 1.04 & 1.10 & 2.61 & 2.44 & 1.93 & 2.26 & 1.28 & 0.98 & 1.71 & 0.16 & - \\
\hline & CV & 1.30 & 1.75 & 0.39 & 0.58 & 0.60 & 1.75 & 1.68 & 0.68 & 1.00 & 1.41 & 0.83 & 0.94 & 0.24 & - \\
\hline
\end{tabular}



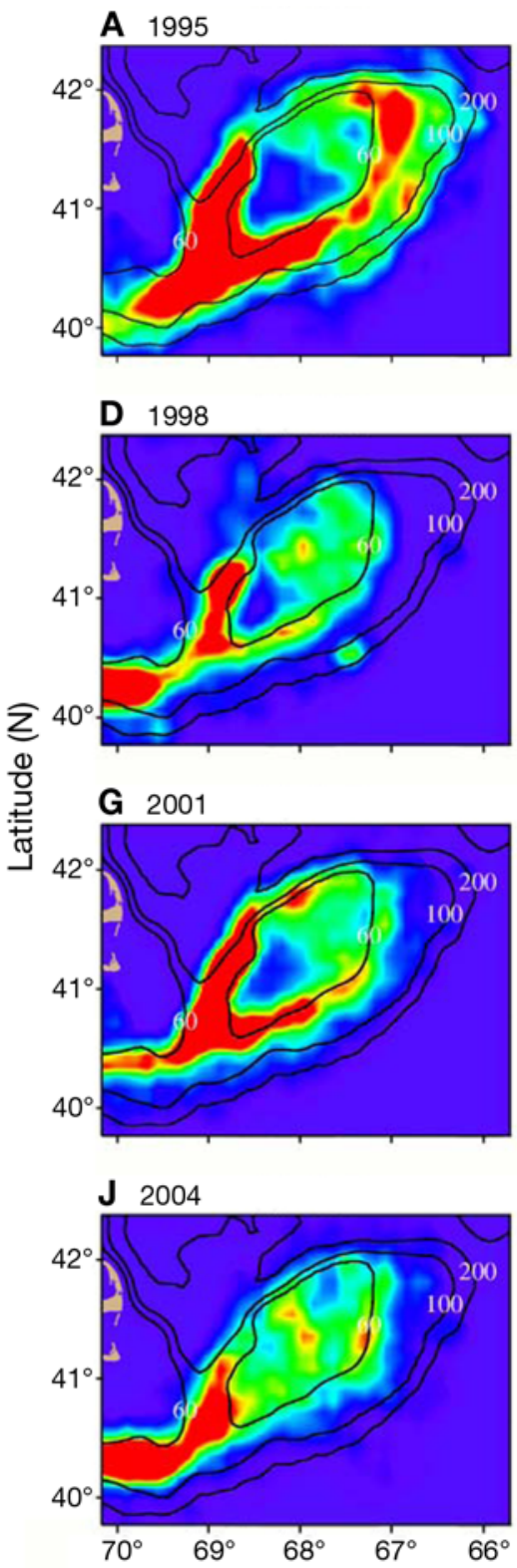

B 1996

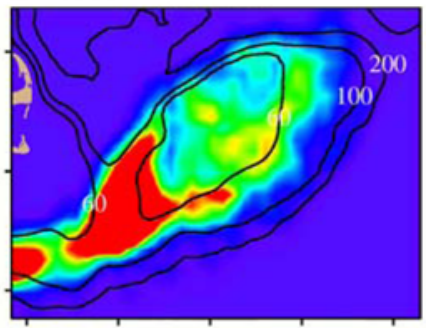

E 1999

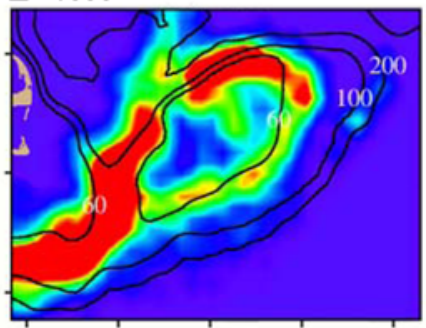

H 2002

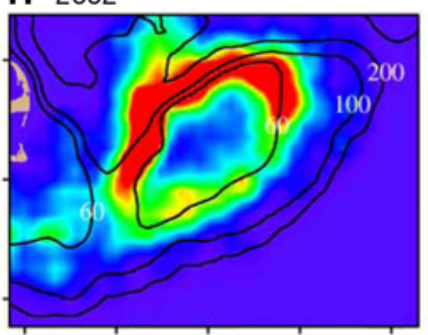

K 2005

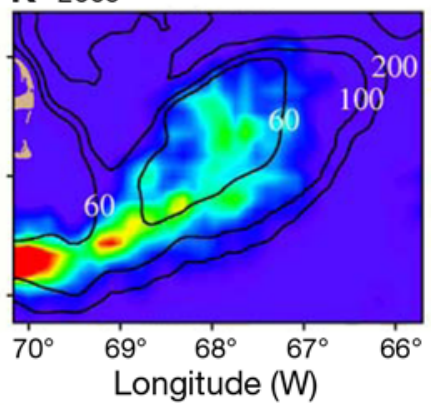

C 1997

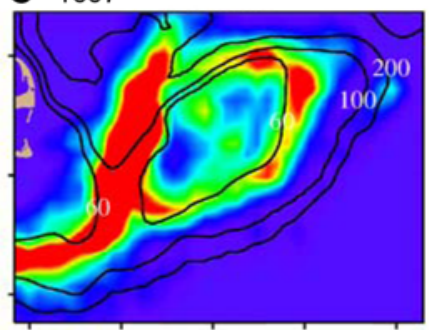

F 2000

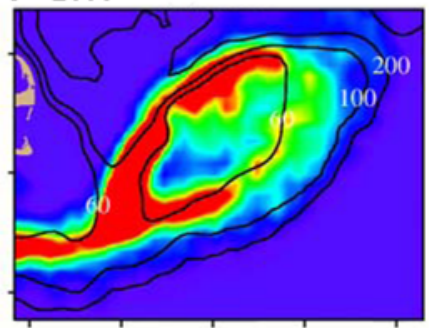

I 2003

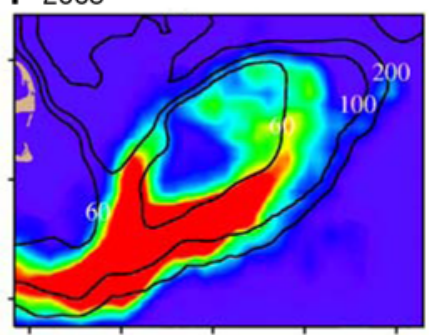

L Average

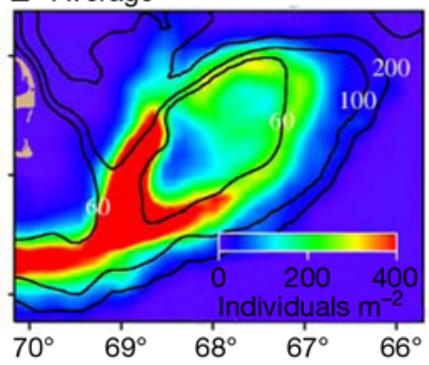

Fig. 7. Placopecten magellanicus. Abundance of settled larvae on Georges Bank [GB] and in the Great Southern Channel (GSC) predicted by the Standard run

with an abundance ranging from 99 larvae $\mathrm{m}^{-2}$ in 2002 to 500 larvae $\mathrm{m}^{-2}$ in 1999 and a global mean of 303 larvae $\mathrm{m}^{-2}$ over the $11 \mathrm{yr}$. A considerable number of larvae were also found to drift into the deep waters of the GOM interior in 1997 (26\% of total spawning) and in $2002(20 \%$ of total spawning).

\section{Exchange of larvae between scallop subpopulations}

The model predicted important larval exchanges between different scallop subpopulations (Fig. 8). Larvae that settled on the Northeast Peak (NEP) of GB were primarily spawned on the southern flank of GB and on the western side of the GSC. Larvae settled on the northern flank were spawned on the southern flank with a fraction spawned on the northern flank. Larvae settled on the southern flank were mainly spawned in the northern sections of the GSC, with a small fraction spawned on the NEP and southern flank. Larvae settled in the GSC were mostly spawned on the NEP, including the east end of the south flank. Larvae settled in the NLCA and the MAB areas were mostly spawned at the southern and southeastern side of GB, with a small contribution from the western side of the GSC. Larvae spawned on the southeastern portion of 

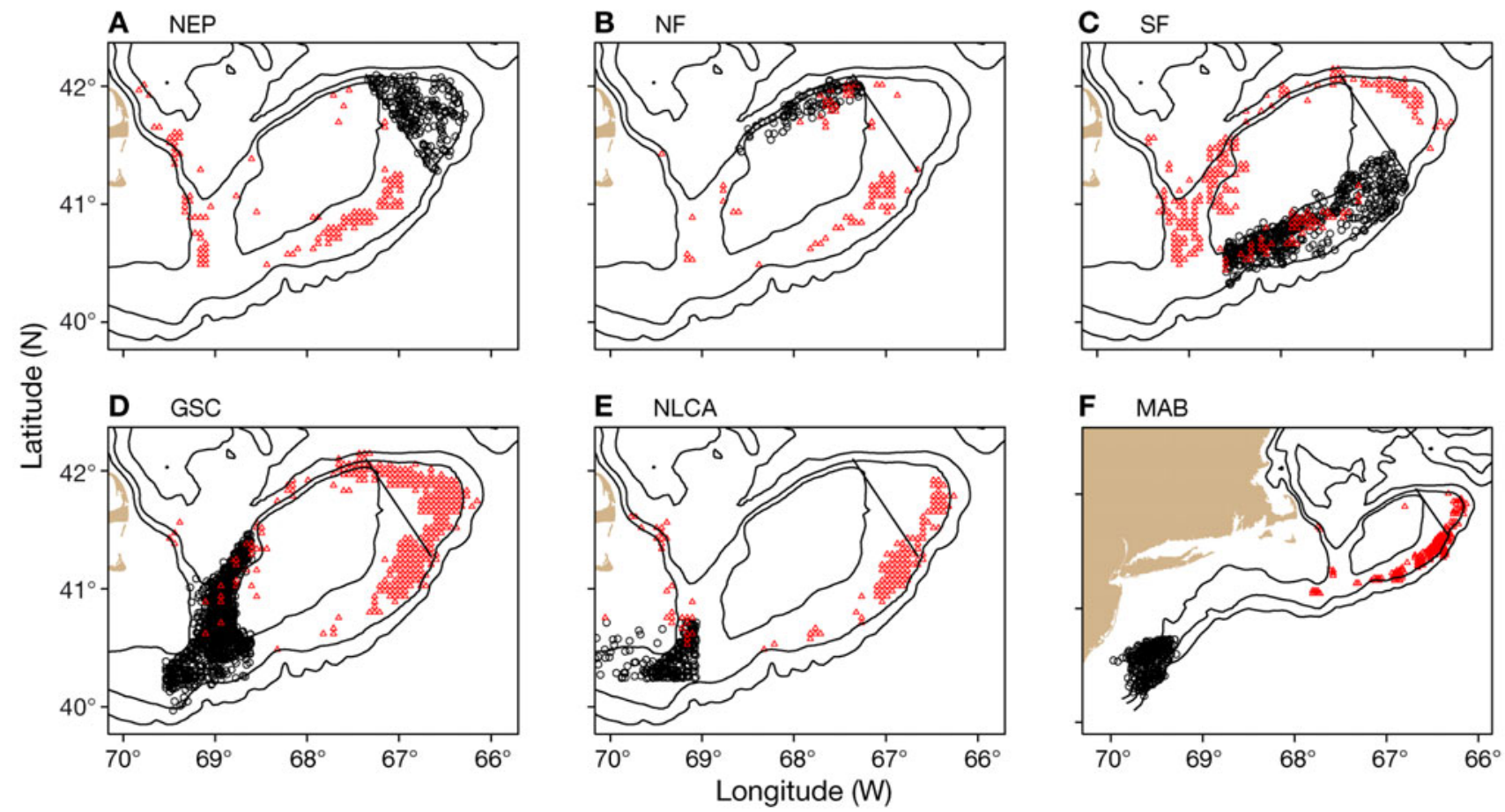

Fig. 8. Placopecten magellanicus. Spawning grounds (triangles) of settled larvae (circles) in different scallop beds simulated by the Standard run in 1995. The simulation of 1998 was used for the MAB area because no larvae were found to drift into this region in the 1995 simulation (NEP: Northeast Peak; NF: Northern flank of (GB); SF: Southern flank of Georges Bank (GB); GSC: Great Southern Channel; NLCA: Nantucket Lightship Closed Area; MAB: Middle Atlantic Bight south to Hudson Canyon). Continuous lines: 60, 100, and $200 \mathrm{~m}$ isobaths

GB can thus settle in the GSC, NLCA, or in the MAB. However, the spawning locations were slightly different for the 3 settlement grounds. Most of the larvae that settled in the MAB area were spawned close to the shelf-break region around the 100 and $200 \mathrm{~m}$ isobaths where there is a more persistent along-shelf current. Larvae settled in NCLA were spawned mostly inside the $100 \mathrm{~m}$ isobath, whereas larvae settled in the GSC were spawned in proximity to the tidal-mixing-front recirculation.

Strictly speaking, none of the major scallop beds was found to be self-sustaining due to the exchanges

Table 3. Placopecten magellanicus. Larval net survivorship (ratio between the total number of larvae settled and spawned in a given region) and the percentage of larvae spawned in situ over total settlement: GB: Georges Bank; GSC: Great Southern Channel; NLCA: Nantucket Lightship Closed Area. These subdomains are demarcated in Fig. 1

\begin{tabular}{|lcccccc|}
\hline & \multicolumn{3}{c}{$\begin{array}{c}\text { Net survivorship } \\
\left(\times 10^{-5}\right)\end{array}$} & \multicolumn{3}{c|}{ In situ spawned larvae } \\
& Max. & Min. & Mean & Max. & Min. & Mean \\
\hline GB & 6.40 & 1.84 & 4.05 & 68 & 37 & 54 \\
GSC & 14.6 & 1.93 & 7.92 & 44 & 3 & 16 \\
NLCA & 12.4 & 2.63 & 7.33 & 4.0 & 0.0 & 1.0 \\
\hline
\end{tabular}

of large quantities of larvae over long distances. At the larval level, GB and the GSC regions functioned as a single system. To the total number of larvae settled on GB, larvae spawned in the GSC contributed from $32 \%$ in 2003 to $63 \%$ in 1998 with an average of $46 \%$ over the 11 yr (Table 3). Similarly, larvae spawned on GB accounted for $56 \%$ in 2005 up to $97 \%$ in 1996 with a global average of $84 \%$ of the total number of larvae settled in the GSC. Most of the larvae settled in NLCA were spawned on GB and in the GSC, with only $1 \%$ on average spawned in situ.

\section{Survivorship}

The survivorship of larvae is primarily determined by mortality. As a constant mortality was used in this work, the predicted survivorship did not take into account spatial and temporal variations in starvation and predation. The age of larvae at settlement ranged from 35 to $65 \mathrm{~d}$. Given that an instantaneous mortality of $0.25 \mathrm{~d}^{-1}$ was used, the biological survivorship from spawning to settlement ranged from $1.6 \times 10^{-4}$ to $1.0 \times$ $10^{-7}$, depending on the suitability of the substrate. The average survivorship was around $1.0 \times 10^{-4}$ without 
notable variations between different scallop beds and years.

The above biological survivorship does not take into account losses through dispersion. We employ the term 'net survivorship' to include both mortality and dispersion losses. It is the ratio between the total number of larvae settled and the total number of larvae spawned in a given region. The net survivorship on GB ranged from $1.8 \times 10^{-5}$ in 2005 to $6.4 \times 10^{-5}$ in 2003 , with an average of $4.05 \times 10^{-5}$ over the $11 \mathrm{yr}$. The net survivorship in the GSC was higher than that on GB due to the influx of larvae spawned on GB, ranging from $1.9 \times 10^{-5}$ in 2005 to $14.6 \times 10^{-5}$ in 1998 and averaging $7.9 \times 10^{-5}$.

A previous analysis found scallop recruitment to vary up to 40-fold on an interannual basis in the region (Hart \& Rago 2006) whereas the model predicted a 5 -fold interannual variability in larval settlement at age-0 as driven by physical dispersion. The aforementioned recruitment variability study considered 2-yr-old scallops, thus including the post-settlement mortality during the first $2 \mathrm{yr}$. The only source of recruitment variability in the present work is derived from physical dispersion. This indicates that the other critical factors, including fecundity and biological mortality during the pelagic and first $2 \mathrm{yr}$ of postsettlement, could contribute a factor of 8 to the interannual variability in recruitment.

\section{Sensitivity analysis}

The sensitivity analyses were compared to the Standard run using a $t$-test based on the total number of larvae settled in each region $(\mathrm{GB}, \mathrm{GSC}, \mathrm{MAB}$, and GOM; Table 2). In this section, we used a critical significance level of 0.05 to reject the null hypothesis that a sensitivity-analysis run is undifferentiated from the Standard run (i.e. supporting the alternative hypothesis that the 2 compared runs differ). For GB, the Random-walk run and the Surface-drift run were not significantly different from the Standard run, although these 2 runs predicted slightly higher settlement on average on GB than the Standard run. The 50-m-drift run and the Reduced- and Increasedsettlement-probability runs were statistically different from the Standard run. The 50-m-drift run predicted higher settlement on GB $(+71 \%)$ than the Standard run on average over the $11 \mathrm{yr}$, with the biggest difference in 2005 and the smallest difference in 2002 (+160 and $+34 \%$, respectively). The Reduced-settlement-probability run predicted lower settlement $(-12 \%)$, and the Increased-settlement-probability run predicted higher settlement $(+10 \%)$ on GB than the Standard run, but the differences were much smaller than that between the 50-m-drift and the Standard runs.

For GSC, all sensitivity-analysis runs except the 50-m-drift run were significantly different from the Standard run (Table 2). The Random-walk and the Surface-drift runs both predicted a lower (-39 and $-54 \%$ ) total number of larvae settled in the GSC than the Standard run. The largest differences were in $1995(-57$ and $-79 \%)$ and the smallest differences were in $2005(+46$ and $+28 \%)$ for the Random-walk and Surface-drift runs, respectively. The Reducedsettlement-probability and Increased-settlement-probability runs predicted lower $(-10 \%)$ and higher $(+7 \%)$ total settlement of larvae in the GSC on average than the Standard run, but these differences were relatively smaller than that of the previous 2 sensitivityanalysis runs.

For MAB, both the Random-walk and Surface-drift runs predicted significantly higher (+86 and $+129 \%$, respectively) total settlement on average than the Standard run. For GOM, the Surface-drift run predicted over 3 times more larvae drifted into the deep gulf than the Standard run. The 50-m-drift run predicted lower $(-42 \%)$ and the Increased-settlementprobability run predicted higher $(+26 \%)$ total number of larvae drifted into the deep interior waters of GOM, whereas the Random-walk run and the Reducedsettlement-probability run were statistically undifferentiated from the Standard run.

\section{DISCUSSION}

\section{Sensitivity analysis}

The depth of drift played a significant role in determining larval dispersion and retention. In the Surfacedrift and Random-walk runs, the depth range of larval drift was shallower than that in the Standard run, and as such, more larvae were transported down to the MAB and dispersed into the GOM interior. On the other hand, the greater depth of drift in the 50-m-drift run led to reduced transport of larvae out of the spawning ground. The along-shelf current was stronger in the surface layer than in deeper layers, so that more larvae were transported to the MAB when drifting in the surface layer than in deeper layers. Surface wind forcing can also alter larval trajectories, leading to increased dispersion.

The question arising from this result of the sensitivity analysis is whether scallop larvae conduct diel vertical migration, and if so, how this can influence their dispersion during the pelagic phase. Based on mesocosm experiments, Gallager et al. (1996) reported diel vertical migration of sea scallop larvae, with aggregations 
at the surface during the night and at the thermocline during the day. However, the artificial thermocline was only $4 \mathrm{~m}$ deep, and the distance of diel migration was about $3 \mathrm{~m}$. This depth range is practically in the surface layer in the true ocean and on GB. Field observations on GB did not reveal significant diel differences in scallop larval distributions in the water column (Tremblay \& Sinclair 1990). The larval center of mass varied from 12 to $35 \mathrm{~m}$ in different locations and time, but without any diel patterns. Instead, the depth of the larval center of mass was essentially controlled by the variation in the thermocline. With limited ability to migrate, it appears difficult for scallop larvae to overcome the surface mixing layer within a short period of time. Based on the observation above, it is unlikely that larval diel vertical migration can significantly influence their dispersion in this system. However, the mechanism by which scallop larvae maintain their position at the thermocline and the influence of thermocline variation on scallop larval dispersion remain to be investigated in future applications.

Reduced settlement probability resulted in slower settlement and consequently lower retention, whereas increased settlement probability led to more rapid settlement and thus higher retention and lower dispersion. As the settlement probability is primarily determined by the suitability of the substrate, substrate types can thus influence larval dispersion according to our sensitivity analysis. Larval settlement can last up to 1 mo. The extended pelagic phase due to unsuitable substrate types results in a longer period of time for larvae to drift in the water column. Moreover, larvae have a high mortality in the water column so that the extended pelagic phase can lead to higher mortality losses and thus lower net retention rates.


Fig. 9. Residual surface current and temperature averaged in October in 1995 (well organized tidal-mixing-front recirculation, weak along-shelf current, and good year class of larval settlement on Georges Bank), 1998 (cold-water intrusion, deteriorated tidal-mixing-front recirculation, strong along-shelf current, and poor year class), and 2002 (without coastal current cross over of the Great Southern Channel and poor year class). Continuous lines: 60, 100, and $200 \mathrm{~m}$ isobaths 
strengthened the along-shelf current on the southern flank of GB, which carried a large portion of larvae away from the region. In 1995, however, the tidal-mixing-front recirculation was strong and well organized, which helped to retain most of the larvae on GB. The coldwater intrusion in 1998 was linked to a climate event in 1996 that affected the slope water circulation along the northwestern Atlantic continental shelf. The North Atlantic Oscillation Index dropped from the general positive to a negative mode for a single year in 1977, 1979, 1985, 1987, and 1996 (Greene \& Pershing 2003). The slope water circulation responded to each of these climate events with a 1 to 2 yr time lag, and the response to the 1996 event was the most dramatic, leading to the cold-water intrusion in the GOM and on GB in 1998.

One point of interest to sea scallop fishery management is that the implementation of the closed areas on GB did not appear to have significantly improved scallop recruitment on GB. However, impressive recruitment has been observed in the MAB during recent years, which has subsequently caused the region to take the lead in sea scallop landings (Stokesbury et al. 2004, Hart \& Rago 2006). Our simulation showed a potential link between the fishery closure on GB and scallop recruitment in the MAB. It has been estimated that the scallop biomass in the closed areas on GB increased up to 25-fold compared to the pre-closure period (Stokesbury 2002, Stokesbury et al. 2004, Hart \& Rago 2006). These increased spawning stocks on GB can provide abundant larvae available for transport to the MAB in years when the along-shelf current is favorable. Current drifting can also partially explain the weak spawner-recruit relationship in the closed areas. Our simulations show little in situ settlement on GB and in the GSC. In years when the current system is in favor of long-distance larval transport, the spawner-recruit relationship will then deteriorate on local scales.

\section{Larval retention and exchange between subpopulations}

Larval retention and exchange between subpopulations on GB have been a concern over the years. Tremblay et al. (1994) conducted a pioneer modeling analysis on scallop larval drift and settlement on GB and pointed out that the tidal-mixing front recirculation played a key role in larval retention on GB. Substantial larval exchanges between subpopulations were also simulated, with most of the larvae settled on the NEP being spawned in the GSC and those settled on the southern flank being spawned on the NEP. Our study extended the modeling analysis of scallop larval drift and settlement to a multiyear time scale and shed new light on the mechanisms controlling larval dispersion and settlement. Variations in the tidal-mixing-front recirculation can alter the retention rate of scallop larvae on GB on an interannual basis. In 1998, for example, the recirculation at the tidal-mixing front was much weaker and the along-shelf current was stronger than that in 1995 (Fig. 9). As a result, a large fraction of larvae drifted out of GB in 1998, whereas most of the larvae were retained on GB in 1995. The relative strength between the tidal-mixing-front recirculation and the along-shelf current primarily determines the retention rate of scallop larvae on GB.

The WMCC bifurcates near Cape Cod with 1 branch crossing the northern end of the GSC and flowing toward GB. At the northwestern corner of GB, it joins the tidal-mixing-front recirculation and continues towards the northern flank (Fig. 9). The coastal-current crossover and the tidal-mixing-front recirculation are the basic mechanisms for larval exchange between the GSC and GB. In some years (1997, 1999, and 2002), larvae were dispersed into the deep waters of the GOM interior at the retroflection of the tidal-mixing-front recirculation at the northwestern corner of GB (Fig. 7). There was no coherent wind pattern among these 3 years (Fig. 10), but a weak coastal current without crossover in the northern GSC was a common feature during these years. Strong coastal currents and crossover appear to provide favorable conditions for larvae to be conveyed from the GSC onto GB, whereas weakness in or absence of the crossover leads to larval loss from the northern end of GSC into the deep waters of GOM.

Larval dispersion, retention, and settlement depend not only on the current patterns, but also on the geographical location of the larvae. Although the distribution of the spawning stock was unchanged, drifting in the surface layers varied from year to year due to variability in external forcing such as wind. Given the complexity of the circulation, a small shift in larval position in the current system can lead to large variations in settlement location. As shown in Fig. 8, larvae close to the tidal-mixing-front recirculation on the southern flank of GB are more likely to be retained on $G B$, whereas those in the shelf-break region can be transported down to the MAB. Surface wind forcing can alter larval positions and thus change their drifting trajectories during the pelagic phase. Larval retention to GB and the GSC was particularly high in 1995, 2000, and 2003. These years were characterized by low wind stress (Fig. 10). By contrast, large numbers of scallop larvae were transported down to the MAB in 2004 and 2005, 2 years that were characterized by relatively strong north-northeasterly wind. Although it is difficult to isolate a single factor responsible for larval dispersion, wind appears to be a key factor. 

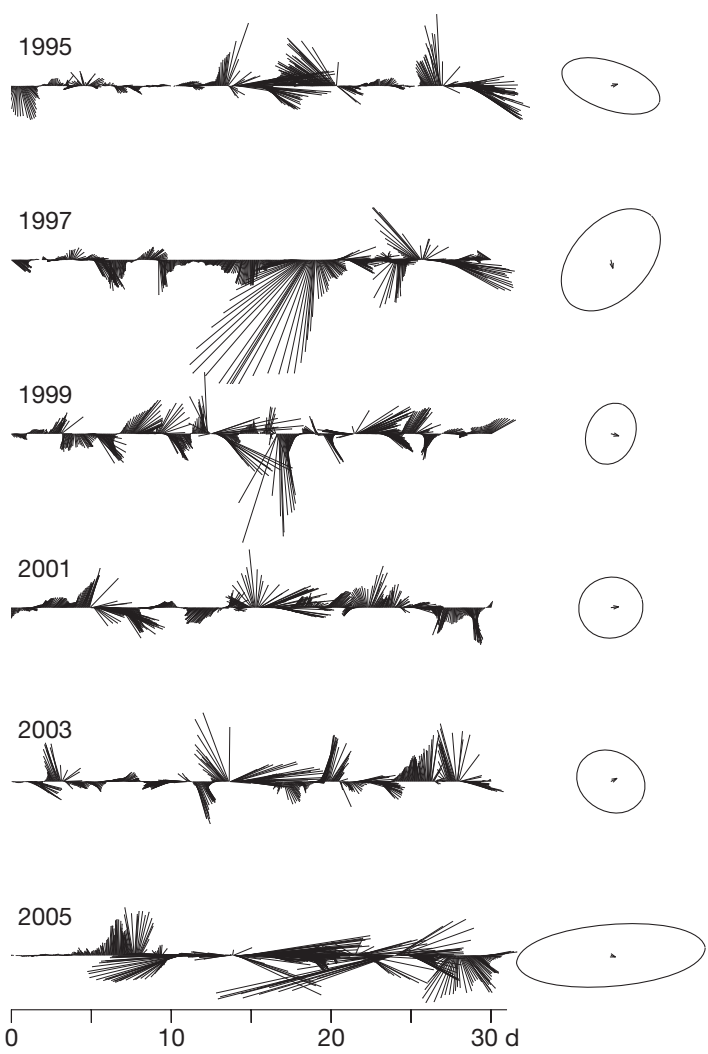

In summary, the key findings of our study are (1) sea scallop larvae are capable of long-distance dispersal from GB to MAB during their pelagic phase and (2) the larval exchange between the GB and GSC scallop beds implies a strong interconnection of those subpopulations. However, the long-distance larval transport and exchange between GB and the GSC show considerable interannual variations due to changes in the along-shelf current and in the tidal-mixing-front recirculation. Both remote forcing such as the Nova Scotian Shelf inflow and local wind forcing can alter the along-shelf current and deteriorate the tidal-mixing front recirculation, leading to interannual variations in scallop larval dispersion and settlement. Sensitivity analysis shows that the larval drifting depth plays a significant role in determining larval dispersion, with shallow drifting depth resulting in high dispersion and low retention on GB and vice versa, but the fundamental findings concerning larval longdistance transport and exchanges remain coherent with different model setups. Fishery management is usually based on geographically-divided stocks. Our study suggests that the spatial scale of larval drifting within the framework of ocean current needs to be considered in fishery management. When 2 or more fishery stocks are connected, as are sea scallops on GB and in the MAB, a global management plan considering both stocks can be more efficient than those targeting a single stock.
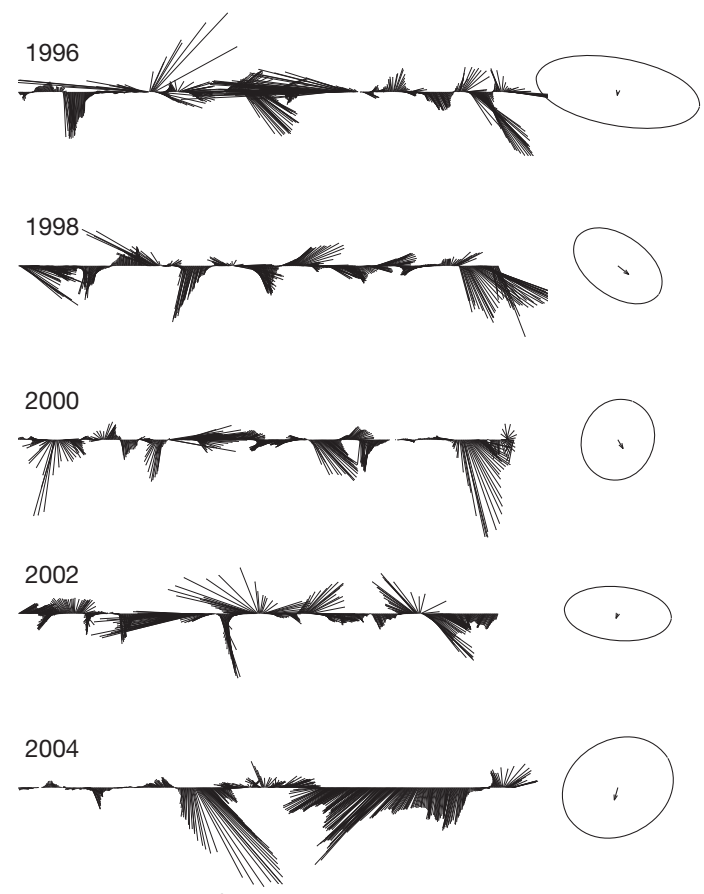

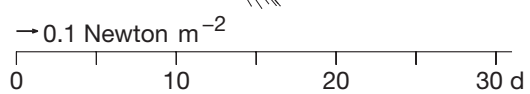

Fig. 10. Hourly wind stress and variance-dependent wind ellipse in October on top of Georges Bank $\left(41.27^{\circ} \mathrm{N}, 67.80^{\circ} \mathrm{W}\right)$ over the 11 simulated years. Arrows in the ellipses are the monthly average of wind stress

Acknowledgements. We thank Dr. A. Vézina and 2 anonymous reviewers for their constructive comments during the revision of this paper. This study was supported by the research programs of Scallop Fishery Assessment and New England Multispecies Survey at the School for Marine Science and Technology (SMAST), University of Massachusetts Dartmouth, through NOAA grants DOC/NOAA/NA04NMF4720332, DOC/NOAA/ NA04NMF4720339, DOC/NOAA/NA05NMF4721131，DOC/ NOAA/NA05NMF4721132, DOC/NOAA/NA06NMF4720096, and DOC/NOAA/NA06NMF4720097 and the US GLOBEC/ Georges Bank Program through NOAA Grant NAA160P2323 and NSF grants OCE0227679 and OCE-0234545. This is SMAST-UMD contribution number 09-0102.

\section{LITERATURE CITED}

Beardsley RC, Chapman DC, Brink KH, Ramp SR, Schlitz R (1985) The Nantucket Shoals Flux Experiments (NSFE79). Part I: A basic description of the current and temperature variability. J Phys Oceanogr 15:713-748

Beardsley RC, Butman B, Geyer WR, Smith P (1997) Physical oceanography of the Gulf of Maine: an update. In: Proc Gulf of Maine Ecosystem Dynamics Scientific Symposium and Workshop Report 97-1. Regional Association for Research in the Gulf of Maine, Hanover, NH, p 39-52

Brand AR (1991) Scallop ecology: distributions and behaviour. In: Shumway SE, Parsons GJ (eds) Scallops: biology, ecology and aquaculture, Elsevier, New York, p 585-623

> Chapman DC, Beardsley RC (1989) On the origin of shelf water in the Middle Atlantic Bight. J Phys Oceanogr 19:384-391

Cowles GW, Lentz SJ, Chen C, Xu Q, Beardsley RC (2008) Comparison of observed and model-computed low frequency 
circulation and hydrography on the New England Shelf. J Geophys Res 113, C09015, doi:10.1029/2007JC004394

Culliney JL (1974) Larval development of the giant scallop Placopecten magellanicus (Gmelin). Biol Bull (Woods Hole) 147:321-332

DiBacco C, Robert G, Grant J (1995) Reproductive cycle of the sea scallop, Placopecten magellanicus (Gmelin, 1791), on northeastern Georges Bank. J Shellfish Res 14:59-69

Fratantoni PS, Pickart RS (2003) Variability of the shelf break jet in the Middle Atlantic Bight: internally or externally forced? J Geophys Res 108, C563166, doi:10.1029/2002JC001326

Gallager SM, Mannuel JL, Manning DA, O'Dor R (1996) Ontogenetic change in the vertical distribution of giant scallop larvae, Placopecten magellanicus, in 9-m deep mesocosms as a function of light, food, and temperature stratification. Mar Biol 124:679-692

Greene CH, Pershing AJ (2003) The flip-side of the North Atlantic Oscillation and modal shifts in slope-water circulation patterns. Limnol Oceanogr 48:319-322

Hart DR, Chute AS (2004) Essential fish habitat source document: sea scallop, Placopecten magellanicus, life history and habitat characteristics. NOAA Tech Memo NMFS NE189, Woods Hole, MA

Hart DR, Rago PJ (2006) Long-term dynamics of U.S. Atlantic sea scallop Placopecten magellanicus populations. N Am J Fish Manage 26:490-501

Houghton RW, Aikman F III, Ou HW (1988) Shelf-slope frontal structure and cross-shelf exchange at the New England shelf-break. Cont Shelf Res 8:687-710

Langton RW, Robinson WE, Schick D (1987) Fecundity and reproductive effort of sea scallop Placopecten magellanicus from the Gulf of Maine. Mar Ecol Prog Ser 37:19-25

Loder JW, Shore JA, Hannah CG, Petrie BD (2001) Decadalscale hydrographic and circulation variability in the ScotiaMaine region. Deep-Sea Res II 48:3-35

Lough RG, Smith WG, Werner FE, Loder JW and others (1994) Influence of wind-driven advection on interannual variability in cod egg and larval distributions on Georges Bank: 1982 vs 1985. ICES Mar Sci Symp 198:356-378

Lozier MS, Gawarkiewicz G (2001) Cross-frontal exchange in the Middle Atlantic Bight as evidenced by surface drifters. J Phys Oceanogr 31:2498-2510

McGarvey R, Serchuk FM, McLaren IA (1992) Statistics of reproduction and early life history survival of the Georges Bank sea scallop (Placopecten magellanicus) population. J Northwest Atl Fish Sci 13:83-99

Melvin GD, Dadswell MJ, Chandler RA (1985) Movement of scallop (Placopecten magellaniucs) (Gmelin, 1791) (Mollusca: Pectinidae) on Georges Bank. Can Atl Fish Sci Advis Comm Res Doc 95

Mullen DM, Moring JR (1986) Species profiles: life histories and environmental requirements of coastal fishes and invertebrates (North Atlantic). Sea scallop. Biol Rep US Fish Wildl Serv

Murawski SA, Brown R, Lai HL, Rago PJ, Hendrickson L (2000) Large-scale closed areas as a fishery-management tool in temperate marine systems: the Georges Bank experience. Bull Mar Sci 66:775-798

Naidu KS, Robert G (2006) Fisheries sea scallop. Placopecten magellanicus. In: Shumway SE, Parsons GJ (eds) Scallops: biology, ecology and aquaculture. Elsevier, Amsterdam, p 869-905

NEFSC (2004) The 39th northeast regional stock assessment workshop assessment report. US Dep Commer, Northeast Fish Sci Cent Ref Doc 04-10b, Woods Hole, MA
NEFSC (2007) The 45th northeast regional stock assessment workshop (45th SAW) report. US Dep Commer, Northeast Fish Sci Cent Ref Doc 07-16, Woods Hole, MA

Noble M, Butman B, Wimbush M (1985) Wind-current coupling on the southern flank of Georges Bank: variation with season and frequency. J Phys Oceanogr 15:604-620

Page FH, Sinclair M, Naimie CE, Loder JW, Lozier RJ, Berrien PL, Lough RG (1999) Cod and haddock spawning on Georges Bank in relation to water residence times. Fish Oceanogr 8:212-226

- Polacheck T, Mountain D, McMilan D, Smith W, Berrien P (1992) Recruitment of the 1987 year class of Georges Bank haddock (Melanogrammus aeglefinus): the influence of unusual larval transport. Can J Fish Aquat Sci 49:484-496

Posgay JA (1976) Population assessment of the Georges Bank sea scallop stocks. ICES CM 1976/K:34

Posgay JA (1981) Movement of tagged scallops on Georges Bank. Fish Rev 43:19-25

Posgay JA, Norman KD (1958) An observation on the spawning of the sea scallop, Placopecten magellanicus (Gmelin), on Georges Bank. Limnol Oceanogr 3:478

Shumway SE, Barter J, Stahlnecker J (1988) Seasonal changes in oxygen consumption of the giant scallop, Placopecten magellanicus (Gmelin). J Shellfish Res 6:89-95

Stewart PL, Arnold SH (1994) Environmental requirements of the sea scallop (Placopecten magellanicus) in eastern Canada and its response to human impacts. Can Tech Rep Fish Aquat Sci 2005:1-36

Stokesbury KDE (2002) Estimation of sea scallop abundance in closed areas of Georges Bank, USA. Trans Am Fish Soc 131:1081-1092

Stokesbury KDE, Harris BP, Marino MC II, Nogueira JI (2004) Estimation of sea scallop abundance using a video survey in off-shore US waters. J Shellfish Res 23:33-40

> Thouzeau G, Robert G, Smith SJ (1991) Spatial variability in distribution and growth of juvenile and adult sea scallop Placopecten magellanicus (Gmelin) on eastern Georges Banks (Northwest Atlantic). Mar Ecol Prog Ser 74: 205-218

Townsend DW, Thomas AC, Mayer LM, Thomas MA, Quinlan JA (2006) Oceanography of the northwest Atlantic continental shelf. In: Robinson AR, Brink K (eds) The sea, Vol $14 \mathrm{~A}$, The global coastal ocean interdisciplinary regional studies and syntheses. Harvard University Press, Cambridge, MA, p 119-168

- Tremblay MJ, Sinclair M (1990) Sea scallop larvae Placopecten magellanicus on Georges Bank: vertical distribution in relation to water column stratification and food. Mar Ecol Prog Ser 61:1-15

- Tremblay MJ, Loder JW, Werner FE, Naimie CE, Page FH, Sinclair MM (1994) Drift of sea scallop larvae Placopecten magellanicus on Georges Banks: a model study of the roles of mean advection, larval behavior and larval origin. DeepSea Res II 41:7-49

Twichell DC, Butman B, Lewis RS (1987) Shallow structure, surficial geology and the processes currently shaping the bank. In: Backus RH, Bourne DW (eds) Georges Bank. MIT Press, Cambridge, MA, p 31-37

Visser AW (1997) Using random walk models to simulate the vertical distribution of particles in a turbulent water column. Mar Ecol Prog Ser 158:275-281

> Werner FE, Page FH, Lynch DR, Loder JW and others (1993) Influence of mean 3-D advection and simple behavior on the distribution of cod and haddock early life stages on Georges Bank. Fish Oceanogr 2:43-64

Submitted: April 21, 2008; Accepted: January 7, 2009

Proofs received from author(s): March 23, 2009 